Alexandra N. Lenz (Wien) \& Albrecht Plewnia (Mannheim)

\title{
On Grammar between Norm and Variation
}

\section{Introduction}

Already thirteen years ago, the publishing company Peter Lang Verlag published a (German) volume with the title "Norm und Variation" ("Norm and Variation') (Mattheier (ed.) 1997). Klaus Mattheier, editor at that time, deliberately stuck to the order of the concepts 'norm' and 'variation' although, as he pointed out, that order is misleading:

"Schon die Reihenfolge [...] suggeriert eine bestimmte strukturelle bzw. genetische Reihenfolge der Phänomene, die mit den Verhältnissen in der Sprachwirklichkeit nicht völlig übereinstimmt. Man wird zu der Vorstellung geführt, daß in einer Einzelsprache bzw. in der Sprache allgemein zuerst eine Sprachnorm gegeben ist und die Variation dieser nachgeordnet ist. Der Begriff 'Variation' suggeriert darüber hinaus, daß es eine Norm, einen Gebrauch, einen Usus in der Sprache geben muß, zu dem in der Sprachwirklichkeit beobachtbare sprachliche bzw. sprachsozioloigsche Phänomene 'eine Variation' bilden." (Mattheier 1997: 7) 'The order alone [...] suggests a certain order of the concepts in structure or their generation, which does not correctly correspond with the reality of language. It suggests that, in any given language or even in language in general, a given linguistic norm exists to which a variation is then subordinated. The concept of 'variation' further suggests that there must be a norm, a convention, a custom in this language to which some phenomena, linguistic or linguistic-sociological, are 'a variation'.'

We should, however, in fact turn the order around: It should rather be: "variation and norm', or even better: 'diversity and norm', as it is primarily variation which is expressed in speech production and reception, and this variation "[wird] erst in einem zweiten Schritt durch die Alterität, den Bezug auf das soziale Gegenüber, in einem Usus bzw. in Normen ,eingefangen'." (Mattheier 1997: 7). 'Regardless of this fact, the pair of concepts 'norm and variation' has been established in exactly this order as a collocation, ${ }^{2}$ and can therefore be found in the title of this volume.

Although the titles correspond, the volumes are quite different, particularly because our volume focuses on the systematic level of grammar. The volume

1 'Only in a second step is it 'caught' by alterity, by reference to the social counterpart, in a custom, i.e. a norm.'

2 With regard to German, the preference is clear: A Google search (14th April 2010) returned 12,600 results for the German sequence of terms "Norm und Variation" in this order, while only 201 results for "Variation und Norm" came up. The English term "norm and variation" mirrors this preference with 60,600 results, outnumbering "variation and norm" which achieved 41,300 hits. 
published in 1997 contains - in addition to a larger number of theoretical contributions - empiric investigations dealing almost exclusively with phoneticophonological phenomena of norm and variation. Only very marginally are other systematic levels discussed. Syntax is a neglected field within the study of linguistic variation, which certainly is partly based on the belief (appearing in literature again and again) that "Syntax ist prinzipiell weniger variabel als Phonetik und Morphologie und daher auch weniger funktionell einsetzbar." (HennMemmesheimer 1997: 55) ${ }^{3}$ One of the declared objectives of this volume is to empirically tackle the thesis that syntax offers few possibilities of variation.

Analysing the relationships between norm, variation and grammar, we have taken on a field of study which emerged only recently: While the potentially conflicting concepts of norm and variation have often been the focus of many sociolinguistic and other variation studies, such studies are rarely based on the linguistic level of grammar, and even less rarely on syntax. A look into grammar-oriented research literature demonstrates that an interest in variation has only emerged over the previous decades and significantly increased only today. As it is socioculturally determined, a discussion of norms always has to take existing sociocultural backgrounds into consideration. Taking this into account, the discussion and the examples used below - just as the other contributions to the volume - limit themselves to two large modern European languages, mainly German and secondly also English. There is an abundant number of sociolinguistic studies on these languages which may be woven into the discussion.

The present contribution consists of two main parts: The first main part (section 2) focuses first on the concept of norm in general and then on language norms in particular (section 2.1). The objective of our discussion is to sketch, in consideration of the background of current research literature, some crucial elements of (language) norms which are relevant to the context as a whole. Subsequently, we give attention to the phenomenon of grammatical variation which turns out to have become increasingly often a subject of linguistic research and even of public language awareness (section 2.2). The second main part (section 3) deals with fundamental research questions which are also examined by the other contributions to the volume. In theoretical discussions as well as specific empirical analyses on English and German, they epitomise the complex relationship between norm and variation.

'Syntax is principally less variable than phonetics and morphology, and it is therefore more difficult to use it functionally.' 


\section{Norm and Variation}

\subsection{On Language Norms and their Characteristics}

The first contribution to this volume (by Markus Hundt) deals with some very fundamental questions on the topic of language norms and their characteristics. At this point, we will only mention some selected aspects of this field which contribute to the theoretical classification of the complete volume.

As language norms constitute norms whose reference object is language defined in simplified terms - basic features of norms also apply to the discussed concept of language norms. ${ }^{4}$ Thinking about norms and their nature regularly leads to their social conditional factors and value as their main characteristics," in a very basic manner, as Takahashi puts it:

"The term 'norm' [...] generally stands for a measure or criterion for something which gives guidelines for people's acts and forbearances [...]. Out of technical or social necessities, common values come into existence, which are shared and diffused among the community members. When they are internalised and on the whole observed by the members, they are described as "norms“, some of which might be officially or unofficially codified in order to clarify the contents and meet the needs of inquiry and promulgation." (Takahashi 2004: 172)

Gloy represents a similar approach. He focuses on obligation as the key element through which norms function:

"Eine Norm i. e. S. ist der intentionale Sachverhalt einer Verpflichtung (Obligation). Das konstitutive Merkmal 'Obligation' bedeutet: eine Norm verkőrpert zwar håufig, aber keineswegs ausschliesslich ein Richtigkeits- bzw. Korrektheitsurteil; ihr Verpflichtungscharakter kann z.B. auch das Zweckmassige, das Angemessene, das Legale o. a. betreffen. Das Merkmal 'Intentionalităt' bedeutet u.a.: für die Existenz einer Norm ist ihre Formuliertheit (oder gar Statuiertheit) nicht ausschlaggebend. Normen sind inhaltlich bestimmte Regulative, die sich auf die Ausführung oder Unterlassung bestimmter Handlungen und Handlungssequenzen beziehen können ('Handlungs- und Verfahrens-Normen'), auf die Auswahl und Verwendung bestimmter Mittel, die eine Handlung erst konstituieren bzw. ihren Vollzug ermöglichen ('Instrumental-Normen'), auf die Beschaffenheit eines Handlungsergebnisses ('technische oder Produkt-Normen'), schliesslich auf die Inhalte des Denkens, Wunschens, Bewertens und Interpretierens sowie die Form ihrer Entăusserung." (Gloy 2004,392 ) "A norm in the narrower sense is the intentional circumstance of an obligation. The constitutive element of 'obligation' means that a norm often, but not always, typifies a judgement on accuracy or correctness; its obligation element may however also concern the appropriate, adequate, legal or similar. The element of 'in-

Alternative, norm-related concepts are not discussed here; in this respect $\mathrm{cf}$. Gloy 2004: 392 et seq. and Takahashi 2004: 172 et seq.

5 Dovalil (2006: 12-36) provides an extensive overview of other norm definitions. Markus Hundt's article gives a theoretical discussion of the concept of norm (in this volume). 
tentionality' means, inter alia, that it is not decisive for a norm's existence that it has been expressed (possibly even as a statute). Norms are regulative principles, defined by their content, which can relate to the execution or failure of actions or sequences of actions ('norms of actions and procedures'), to the selection and use of certain measures constituting an action or enabling their execution ('instrumental norms'), to the state of a result of an action ('technical norm or product norm'), and finally to the contents of thinking, wishing, evaluating and interpreting, as well as the form expressing them.'

In order to assess language norms, it is further significant to consider that they are acquired as social facts (cf. also Labov 2001: 427-429).

"Social life, including language usage, is governed by norms - socially shared concepts of appropriate and expected behaviour. The most basic of these concepts are acquired in early childhood through socialisation. In the case of language norms this means that the first language norms adopted are the ones of everyday spoken language. Compared to the prescriptive norms of the standardised language, these uncodified norms are perhaps less conscious yet more natural [...] in every sense of the word: they are more numerous, acquired earlier in life and mastered by all native speakers. [...] Norms are inherently social." (Kauhanen 2006: 34)

Language norms can thus be described as a specific type of social norms:

"Unter die [...] sozialen Normen fallen als Teilmenge die Sprachnormen. Letztere sind Erwartungen [...] und/oder explizite Setzungen deontischer Sachverhalte, die ihrem Inhalt zufolge die Bildung, Verwendungsabsicht, Anwendung und Evaluation sprachlicher Einheiten der verschiedensten Komplexitătsgrade regulieren (sollen)." (Gloy 20004: 394) 'Language norms are a subset of social norms. They are expectations [...] and/or explicit settings of deontic circumstances which (intend to) regulate, according to their content, establishment, purpose of usage, application, or evaluation of linguistic elements at numerous levels of complexity.'

As a consequence, as rules, they have to reach a certain level of abstractness, and violations may be socially sanctioned:

"Eine Sprachnorm ist eine historisch veränderliche und aufgrund der Reflexion sozialer Phänomene intersubjektiv existierende Bewusstseinskomponente, die als Regulator sprachlicher Erwartungen und Handlungen funktioniert und die sich auf gleichartige und zahlenmäßig nicht năher bestimmbare Kommunikationssituationen bezieht. Die Verletzung der Sprachnorm beschert dem Sprachbenutzer gewisse (negative) Folgen." (Dovalil 2006: 26) "A language norm is an awareness component that changes historically and exists, due to the reflection of social phenomena, intersubjectively. Its function is to regulate linguistic expectations and actions, and it relates to communication situations equal in type but indeterminable in number. A violation of a language norm leads to (negative) consequences for the language user.'

The decisive element that distinguishes language norms from other norms is their reference object: Language norms codify language and language behaviour. They may refer to an entire language system (e.g. German), to one part of an entire language (e.g. standard language(s) or non-standard varieties, such as dialects, sociolects or technical languages), or even to individual phenomena. 
They refer to aspects such as phrasing, adequacy of situation and evaluation of language. Norms are negotiated behaviour regularities of social groups. In case of language norms, speaker communities constitute such social groups. Language norms fulfil numerous functions: They function as aids to orientation, behaviour guidelines and evaluation standards, both for the speaking individual or for its speaker community, and for norm authorities who check, evaluate and sanction the respective social actions. As the foreword of the renowned German dictionary Duden shows in its first edition, language norms are further assigned forces of language cultivation and even language maintenance:

"Die Sprache unserer Zeit bedarf in der Schule, noch mehr im Leben, wenn jeder außere Zwang gefallen zu sein scheint, sorgsamer Pflege und treuer Hut, um vor Willkür, Verwahrlosung und Verflachung geschützt zu sein. [...] Es geht um das Bestehen der deutschen Sprache überhaupt." (Duden-Grammatik '1935: Foreword) 'The language of our time requires in school, even more so in life, when all exterior constraints seem to have fallen away, careful cultivation and devoted guard in order to be protected from caprice, neglect and growing shallowness. [...] The continued existence of the German language itself is at issue.'

Just as norms in general, language norms show various levels of validity which may or may not correlate with different types of codifications and sanctions. Language norms - as social norms - exist in an articulated and non-articulated form. Among articulated norms, codified norms constitute a specific type. They are not only expressed but also fixed in writing, for example "in legalising files of authorised organisations ('stated norms') or in non-legalising files of other exercising authorities ('informal norms'). Dictionaries play an outstanding role here." (Gloy 2004: 394). ${ }^{6}$ In general, modern European languages have developed codes for the linguistic core areas of their standard languages (pronunciation, grammar, lexis, in particular orthography). The status of a language does, however, not depend on the codification of a language, as, for example, Lower German (cf. Goltz [in this volume]) or Luxemburgian (Letzebuergesch) proof. The language norms of Luxemburgian have been negotiated and put into writing only over the last decades (cf. Gilles/Moulin 2003).

While varieties of standard languages are generally based on codified norms, the norms of non-standard varieties are frequently "subsistent": "The underlying rules do not exist in writing, so that speakers cannot draw back on them to correct their own norms. [...] Standard varieties, on the other hand, have an abundance of rule sets [...]. The codes are used as correctives in countless situations and are binding on official institutions." (Huesmann 1998: 19) The validity of subsistent norms (or "covert norms", Labov 2001: 215-222) is not determined and supported by official institutions but by (partially unconsciously) inherited

On the various types of norms also cf. v. Polenz 1999: 229 et seq. and Hundt (in this volume). 
conventions, values and expectations of the social group who considers the subsistent norms binding.

How valid a norm is can, inter alia, be expressed by the sanctions applied in case of a norm violation. For example, if the grammaticality of a sentence is violated, it is clearly marked as "mistake" in a school essay, influencing the grade. On the other hand, if, due to context, a standard language version is used rather than the local dialect, this choice might be interpreted as disloyalty towards local communities, even leading to an exclusion of the group which is loyal to its dialect (cf. Lenz 2003). Existence and validity of norms become apparent when they are violated. Violations of norms and the sanctions accompanying them therefore essentially influence the constitution of norms. The complex functions of violations of norms in the network of grammaticality, acceptability and the setting up of language norms are dealt with in Markus Hundt's contribution (in this volume). A decisive fact in the discussion of language norms is that the question of norm-compliant or norm-violating language usage can in general only be answered in consideration of the specific situation. What is sanctioned as a marked mistake in a written essay does not have to constitute a violation of a norm in a text message or family conversation. In such contexts, it might not be punished by sanctions and, on the contrary, might be assessed as perfectly adequate communication. Compliance with norms and consequences of norm violations are further controlled by aspects of attitude. If, for example, a language or variety carries a positive evaluative-attitudinal charge, its use can be tolerated or even looked upon favourably, even though the norm stipulates a different language behaviour for just these situations or contexts. The "Covert Prestige" (Trudgill 1983) of non-standard language elements can decisively contribute to the enforcement of destandardisation processes (cf. Auer 1997, Mattheier/Radtke (eds.) 1997, Deumert/Vandenbussche (eds.) 2003, Daneš 2006, Mattheier 1997, Spiekermann 2005). For example, Daneš (1968/1982) states a decreasing competence in and prestige of the standard among the Czech younger generation. Extralingual factors such as increasing social mobility, and growing norm scepticism contribute to the questioning of the validity and legitimisation of standard varieties and to the popularisation and deliteralisation that accompany a loosening of language norms.

At first glance, norm and variation may seem to be opposite terms. Variation (see section 2.2) means the existence of the possibility to choose; it means dynamics, while norm stands (rather) for the opposite, for stability and statics, as it is highlighted by Hermann Paul (1970: 404):

"[Eine i]deale Norm [...] gibt an, wie gesprochen werden soll. Sie verhält sich zu der wirklichen Sprechtatigkeit etwa wie ein Gesetzbuch zu der Gesamtheit des Rechtlebens in dem Gebiete, fur welches das Rechtbuch gilt, oder wie ein Glaubensbekenntnis, ein dogmatisches Lehrbuch zu der Gesamtheit der religiősen Anschauungen und Empfindungen. Als eine solche Norm ist die Gemeinsprache wie ein Gesetzbuch oder ein Dogma an sich unerveränderlich. Veränderlichkeit würde 
ihrem Wesen schnurstracks zuwider laufen. Wo eine Verănderung vorgenommen wird, kann sie nur durch eine ausserhalb der Norm stehende Gewalt aufgedrängt werden." '[An i]deal norm [...] determines how one should speak. It is to real speech activities what a code of law is to the entirety of legal life in the area where the code of law applies, or what a creed, a dogmatic textbook is to the entirety of religious beliefs and sentiments. As such a norm, standard language itself is unchangeable, just as a code of law or a dogma. Changeability would straightway run contrary to its essence. Wherever a change is applied, it can only be imposed by a force outside the norm.'

Language can be such a force, or more exactly: the potential dynamic that is inherent to language, which is also mentioned in the foreword of the 1959 edition of the Duden-Grammatik (The editor's foreword [i.e. Paul Grebe]):

\begin{abstract}
"Wer Tag für die Tag die zahlreichen Anfragen überprüfen kann, die aus allen Kreisen der Sprachgemeinschaft bei uns eingehen, erfahrt am besten die Wahrheit des Humboldt Wortes, daß die Sprache kein Ergon (Werk, statisches Gebilde), sondern eine Energeia (wirkende Kraft) ist, die das 'Worten der Welt' (Weisgerber) tagglich neu vollzieht." (Duden-Grammatik ${ }^{2} 1959: 7$ ) 'Who reviews the numerous queries we receive from all parts of the language community every day, experiences the truth of Humboldt's saying best: that language is not an ergon (work, static structure) but energeia (acting force), performing the "wording of the world" (Weisgerber) anew every day.'
\end{abstract}

If language norms want to "keep up" with their reference objects, they will have to adjust to their continuously changing objects or even precede them promptly, with delay or anticipating. ${ }^{7}$ They are thus only limitedly static and, just as their reference object language indeed "historically changeable" (Dovalil 2006: 26). This applies to norms of both general language and technical language. Research literature leads a controversial discussion about what exactly happens when norms change and new norms emerge, and about their trigger moments and driving factors (cf. also Hundt [in this volume]). According to Gloy (2004: 397), "[w] hat was first made usable for the change of language (Keller 1990), [...]" can be "extended to the genesis of norms. Their derivation from undiscovered habitual processes [...] could be an opportunity to incorporate pre-normative normalities ("regularities") and a subsequently conscious normalisation into a uniform concept of norms, and to account for the dialectic of standardised and standardising processes."

\title{
2.2 Grammatical Variation as an Increasing Research Laboratory and Topic of "Laymen"
}

In the context of current sociopragmatic research results, Peter von Polenz (2000: 28) finds that variation is - in addition to economics, evolution and inno-

Please refer to Gloy 2004: 396 et seq. for a critical discussion of the emergence and change of norms. 
vation - one of the main factors that cause changes of language and any associated dynamics of linguistic norms. Subject to conditions and goals of communication, language users chose, knowingly or unknowingly, available linguistic means which serve - more or less successfully - to fulfill their sociopragmatic, communicative or other demands. In the field of linguistics, it is mainly due to William Labov (see especially 1966, 1972, and more recently 1994 and 2001) that variability and variation have been recognised to be inherent characteristics of language, or speech, through which they moved into the focus of linguistic research (cf. Milroy/Milroy 1997). While variability refers to the general coexistence of alternative language units in a heterogeneous system and in its varieties, variation means the concrete realisation of variability in concrete language use.

Variation and norm are both constants of human existence: the search for the other possibility, being as a variation comprised in every system including grammar, on the one hand; norms as a social fact on the other hand, making reactions to linguistic acts predictable and thereby making linguistic acts themselves calculable. As we have seen above, the term norm, being used as a social (and not primarily linguistic) concept, not only covers directive norms aiming at a codified standard enforced by strong social obligations. It expressively also includes subsistent norms which support every variety, every system; norms to which speakers adhere, more or less consciously. In this meaning, variation not only comprises varying forms or, respectively, cognitive semantic concepts side by side, but also a complex and dynamic system of coexistent and possibly clashing norms with a different status and a different (a.o. local, social) range each, one of which often but not necessarily comes with high social prestige, being the standard norm.

A review of current linguistic research shows that grammar and especially syntax of non-standard varieties is a young but increasingly important research field. In linguistic subdisciplines like syntactic theory and typology, we can observe a growing interest in language (micro-)variation and empirical data (see for example, Barbiers [et al.] (eds.) 2008). The fact that areal varieties, and among them especially dialects are a rich source of data is likewise increasingly recognised and promotes the inclusion of especially syntax into areas of linguistic inquiry that traditionally focused more on other linguistic levels, notably phonetics/phonology, morphology, and the lexicon. With regard to the dialect syntax of West Continental Germanic languages, only few completed or ongoing projects exist. These include the Syntactische Allas van de Nederlandse Dialecten (SAND), which started from an explicitly theoretical interest in microvariation but which also addressed the dialectological need for data from areal variation. The SAND project also implemented standards for the electronic acquisition and availability of data via databases and online language maps (see Barbiers/Comips/Kunst 2007). Concerning the German language area, only 
three syntax projects covering smaller dialect areas can be mentioned up to now. Among them, the Syntaktischer Atlas der Deutschen Schweiz (SADS) definitely ranks first (see Bucheli/Glaser 2002). Besides SADS, the Sprachatlas von Niederbayern (SNiB), a subproject of the Bayerischer Sprachatlas, included a limited number of syntactic phenomena (cf. Eroms [et al.] 2006). Thirdly, the project on "Syntax hessischer Dialekte (SyHD)" may be noted whose work started in summer 2010 (under the direction of Jür Fleischer (Marburg), Alexandra N. Lenz (Vienna), Helmut Weiß (Frankfurt)). Aside from these atlas projects for Dutch and German dialects, other syntax projects on European languages are currently underway (http://www.dialectsyntax.org/). Most of these projects are part of the research network "EdiSyn (European Dialect Syntax)" established by Sjef Barbiers (Meertens Instituut, Amsterdam). Apart from the European atlas projects, a number of smaller dialect syntactic studies from various perspectives have been carried out during the last decades, including: Abraham/Bayer (eds.) 1993, Penner (eds.) 1995, Weiß 1998, Ledgeway 2000, Barbiers/Comips/van der Kleij (eds.) 2002, Cornips/Corrigan 2005, Fleischer 2002, Seiler 2003, Dubenion-Smith 2007. In these works, linguists from very different disciplines (syntacticians, dialectologists, typologists, variationist linguists, sociolinguists and historical linguists) collaborate because dialects offer a unique empirical basis for the analysis of syntactic phenomena.

What was outlined with regard to dialects also applies to the registers in close-to-standard areas. For example, research into the variation of German everyday language or colloquial German has almost completely been limited to lexis and pronunciation. "Variation in grammar, however, has gone almost unnoticed." (Elspaß [in this volume]). One of the first approaches aiming at closing this gap in research is the "Atlas zur deutschen Alltagssprache (AdA)" (atlas on German everyday language), available online under <http://www.uni-augsburg.de/ alltagssprache $>$. Stephan Elspaß presents the abundance of its productive data and mapped results (in this volume).

Also variation on the level of grammar in standard language, or at least close-to-standard language registers, attracts growing interest. The Institut fur Deutsche Sprache in Mannheim, Germany, provides a good example: It currently carries out a project on "Grammatische Variation im standardnahen Deutsch (Vorstudien zu einer 'Korpusgrammatik')" ('Grammar Variation in close-to-standard German [Preliminary Studies for a 'Corpus Grammar']':

"Ziel des Projekts ist die korpusgestutzte Erforschung der Variation im standardnahen Deutsch (einschließlich der Variation im Standard selbst), die längerfristig eine Grundlage fur die Erstellung einer Grammatik des Deutschen bilden soll, in der entgegen der bisher in der Grammatikographie găngigen Praxis - die Variation im Sprachgebrauch gezielt fokussiert und umfassend aufgearbeitet wird." "The goal of the project is to use corpora to study variation as expressed in close-to-standard lan- 
guage (including the variation in standard German itself). In the long run, the study will form a basis for the composition of a German grammar which - contrary to the common method in grammaticography - will focus on and comprehensively investigate variation in language use.'

Just as the articles of the present volume, the mentioned projects are evidence of how productive comprehensive corpus analyses on grammatical variation are in synchrony and diachrony. As the goal of the above mentioned project to create a "grammar of language use" shows, the results of the study of grammar focusing on variation increasingly influence even the codification of linguistic norms themselves. The intention to link codified norms to the reality of language is also expressed in the foreword of the most recent Duden Grammar:

"Die Dudengrammatik beschreibt die geschriebene und die gesprochene Standardsprache der Gegenwart. Dabei fußt sie auf dem aktuellen Forschungsstand. [...] Besonderes Gewicht haben Autoren und Redaktion außerdem auf die Analyse aktueller Sprachbelege und die entsprechende Auswahl an Beispielen gelegt. Durch das Dudenkorpus und modernste elektronische Suchmöglichkeiten konnten große Mengen aktueller Texte, besonders aus der Presse und dem Intemet, ausgewertet werden." (Duden-Grammatik ${ }^{8}$ 2009: Foreword, highlighted by A. N. L./A. P.) 'The DudenGrammatik describes written and spoken contemporary standard language. It is based on the status of current research. [...] Authors and editors attached particular importance to the analysis of current linguistic evidence and a respective selection of examples. By means of the Duden Corpus and state-of-the-art search technologies, large amounts of current texts, in particular from media and the Internet, could be analysed.'

However, an increasing interest in grammatical (micro-)variations and empirical data on grammar is not only found within linguistic research. Also laymen, the speakers themselves and the non-linguistic public, exhibit an increasing interest in grammatical questions, as the popularity of popular science 'guidebooks' or other descriptions of grammatical 'oddities' reflects. Books and series of books such as "Der Dativ ist dem Genitiv sein Tod" by Bastian Sick (2004 et seq.) as regards German, and "Shoots and Leaves. The Zero Tolerance Approach to Punctuation" by Lynne Truss (2005) as regards English bring phenomena and, at the same time, (supposedly?) valid norms and their violations to the attention of individuals and the community. ${ }^{9}$ As regards standard language, "those seeking advice" may also directly consult legitimate norm authorities or draw upon their written codes (normative dictionaries and grammars) in cases of doubt. A large number of reference books and guidebooks exists for standard contemporary German and English, all of them more or less legitimate and well-known. The broad range is completed by institutionalised contact points dealing with written and oral enquiries. The Gesellschaft für deutsche Sprache and the editorial de-

Among linguistic experts, popular scientific guidebooks often provoke criticism, cf. for example the discussion on Bastian Sick's collection of columns at Maitz/Elspaß (2007), or, even more pronounced, Meinunger (2008). 
partment of Duden offer their help with all questions on standard German. It is clearly more difficult for consulters to find assistance with a minority language, linguistic enclave or an institutionalised second-language variety (cf. Goltz [in this volume], Riehl [in this volume] and Mukherjee [in this volume]). Written sets of rules on grammar are in general neither available for dialects and colloquial languages. Exceptions to the rule are areal varieties with supra-regional popularity which - in the age of the Internet - frequently have online platforms, providing them with a more or less official character. ${ }^{10}$

\section{Current Research Questions (on this Volume)}

The present volume aims at giving an insight on the complex interaction between language norms on the one hand and grammatical variation on the other hand, using two closely related modern European languages, German (High German and Low German) and English as examples. We intend to trace out more clearly the multi-dimensional area of conflict in its diverse possibilities resulting from the existence of varying forms and differing norms. Eleven articles in total are intended to show exemplary and from different perspectives with fittingly selected issues from morphology, morpho-syntax, morphophonology, and syntax of especially German (with 9 articles) and secondly also English (with 2 articles) with their respective varieties what different types of constellation can be formed, how norm and variation influence each other, and finally, how this interaction can promote processes of linguistic change. The articles of the volume cover different approaches to the matter. We set value in a proper balance of the subject matters morphology, morpho-syntax, syntax in an embracement of historic perspectives along with the description of processes of linguistic changes, as well as that analyses and reflections referring to single phenomena are accompanied by corpus analyses with statistic value, and finally in a continuous representation of the object languages German and English (with their respective varieties).

Mainly four central topic areas are examined. They are outlined below, explicitly referring to the articles of this volume: firstly, emergence and change of norms and grammatical constructions; secondly, the question of the relationship between codes of norms on the one hand and real language usage on the other hand; thirdly, the competition or co-existence of standard and non-standard language norms; and finally, fourthly, the special situation of subsistent norms in minority languages (regional languages, linguistic enclaves) and "institutionalised second-language varieties".

10 An example is the online appearance of the "Akademie for uns kolsche Sproch" (Acadamy of the dialect Kölsch) where it is possible to graduate with Kölsch-Abirur and even Kölsch-Examen (http://koelschakademie.finbot.com/). 


\section{(l) On Emergence and Change of Norms and Grammatical Constructions}

The main questions arising here are: How do new norms emerge? What roles do factors of acceptability and frequency of a linguistic unit play? Which "new" grammatical phenomena have the stamina to become a norm? What do these phenomena have what linguistic "flashes in the pan" don't have? What do violations of norms contribute to the emergence of new norms and change of existing norms? What factors motivate, support and control violations of norms?

In his article, Markus Hundt argues that in the end, violations of norms substantially contribute to the fact that speakers become at all aware of the existence and validity of norms. Violations of norms and the accompanying sanctions thus also influence the constitution of norms. Accordingly, the speakers themselves have a decisive influence on emergence, stabilisation and change of norms. An analysis of norms thus has to include this "linguistic sovereign" (Ammon 1995) as a central moment. With regard to German and its standard variety (varieties) ${ }^{11}$, fixed and prescriptive norms only exist fully for orthography and partially for orthoepy. However, descriptive norms can also be found for other system levels, for example lexis or grammar. In general, more than giving strict behaviour instructions, they intend to be of "practical aid" (Duden ${ }^{8} 2009$ : Foreword) in cases of doubt.

An essential difference between codified, prescriptive and authorised norms on the one hand and descriptive norms offering guidance on the other hand is, according to Hundt, how explicit the norm is expressed, rather than the claim for validity of both norm types. As he illustrates on the basis of "weird", that is relatively young and not fully accepted syntactic German constructions, syntax, syntactic variation and syntactic norms are a fruitful field of study for the emergence and change of language norms.

In her study, Beate Henn-Memmesheimer shows that it is possible that certain phenomena which do not comply with norms are not really "violations of norms". Her contribution is concerned with grammatical innovations whose semantic/constructional patterns correspond to existing non-conforming patterns of standard German. Growing acceptance, increasing frequency of use and situational contexts of the innovations she analyses are explained by processes of grammaticalisation and exaptation.

\section{(2) On the Relationship of Codes of Norms and 'Real 'Language Usage}

The second topic area focuses on the relationship between codified norms on the one hand and real language usage by speakers and writers on the other hand. In what relationship are language norms, and how do they correlate? Do codes of norms allow for statements and conclusions on real language usage? How does

11 On the question if any and if so, how many standard varieties exist in German, cf. Ammon (1995), Schmidt (2005). 
real language usage influence emergence and change of language norms? What kind of influence would be helpful? How can "long-term variabilities" in standard language registers be explained, although codified norms of the standard language provide for binding rules supporting one version?

Ulrich Busse and Anne Schröder concentrate on the question to what extent codes of norms reflect actual language usage. On the basis of several usage guides and grammar books, they examine whether a change with regard to norms and the acceptability of language variation has taken place over the last century in these publications. Then they compare the results of their studies to 'real language' by looking at real usage in the framework of an extensive corpus analysis. It turns out that the English reference works they used for selected "cases of doubt" provide data that are surprisingly close to the actual language usage.

At times, it is not only reasonable but necessary to consider empirical material when determining norms, as Renata Szczepaniak's contribution (among others) illustrates. In her study on the variation of genitive forms of nouns, Szczepaniak inquires preferences of morphological form alterations within flexion classes which have risen themselves from a long lasting modification process in the phonological system. The variation of the genitives -es and $-s$, still present in contemporary German, is a phenomenon which remains insufficiently described in contemporary grammar books, making it hard to follow particularly for non-native speakers. Only comprehensive empirical analyses, as Szczepaniak provides them, disclose precise (phonological) control factors for both versions, which are essential to explain the variation and to formulate any rules or norms.

\section{(3) On the Competition of Standard and Non-standard Language Norms}

The co-existence and competition of codified norms in standard language on the one hand and usage norms on the other hand are the focus of the third topic area. How do norms of standard language relate to the in general subsistent norms of non-standard varieties (particularly dialects and regiolects)? What role does areal variation play in this competitive situation, also in the awareness of speakers? Where do reflections of areal variations appear in close-to-standard language? Where do subsistent and codified norms overlap? How can we approach subsistent norms empirically? Are there any deviations from standard which can be explained as systematic grammatical options?

It has been generally accepted that standard language and close-to-standard everyday language allows areal variation (cf. Milroy/Milroy 1985); the details, however, are widely unknown. In his contribution, Stephan Elpal3 uses several case studies to examine the areal variation of standard German and close-tostandard everyday language, in the framework of his investigation of the "Atlas 
zur deutschen Alltagssprache". He shows that the data he collected empirically frequently do not correspond with the regionality markers in grammar books.

Jürg Fleischer deals with similar questions in his contribution on the relative order of accusative and dative personal pronouns in German. While the codified standard is relatively clear, data on real language usage are not. Taking various corpora into account, among them historical data, Fleischer is able to show that the factually existing variation is connected with the dialect structure of German.

The dynamic processes of language change are also examined by Christa Dürscheid and Nadio Giger. The system of case markers in the German flexion of nouns is relatively clearly determined by norms; although real language usage shows a certain degree of variation. In particular, Dürscheid and Giger show that many deviations from standard forms in the area of German noun flexions, which are evidenced in their data collection, can be justified in the framework of optimality theory.

Petra Campe is concerned with a completely different level of competing norms. In German, there are several ways to encode adnominal relations, e.g. by means of the case (mostly genitive), by prepositions or by paraphrasing constructions, such as compounds. However, these patterns are not completely equivalent. Campe illustrates their restrictions at individual cases and how their variations need to be modified.

(4) On Subsistent Norms of Minority Languages (Regional Languages, Linguistic Enclaves) and "Institutionalised Second-language Varieties"

The fourth large topic area focuses on the special situation of multilingualism. What are unique norm constellations and conflicts arising in multilingual communities? How are external and internal standards balanced in institutionalised second-language varieties, how in language minority settings? What do speakers of minority languages and speakers of their varieties use as orientation? What roles do umbrella standard languages play with regard to minority languages?

Joybrato Mukherjee shows in his contribution on verb-complementational innovations in Indian English how new regional standard forms establish. He puts into perspective innovative forms in standard Indian English in the area of verb complementation, including 'new' prepositional verbs, 'new' ditransitive verbs and 'new' light-verb constructions. These innovations indicate a certain degree of autonomy on the part of Indian users of English. Specifically, the new forms can be explained as exponents of rationally motivated analogies that Indian English speakers draw between existing formal and semantic templates in British English and the emerging new forms and structures in Indian English. The processes can be described as cases of nativised semantico-structural analogy. As the innovative forms discussed are low-frequency phenomena which are 
used alongside the standard 'native' variants, large corpora are needed to find authentic instances.

Another case which is extraordinarily interesting from a sociolinguistic point of view are languages which have no or only partially fixed norms, despite their official status as a language. One of those languages is Low German, discussed by Reinhard Goltz in his article. Numerous speakers of Low German think this language has no grammar. In fact, Low German has not developed any kind of standard. High German has, for several centuries, assumed the role of a standard language. The immediate neighbourhood of High and Low German in Northern Germany has led to a history of contact over centuries. Generally, structures of the prestigious High German influence elements of the regional language and their interaction. Considering sinking numbers of speakers and decreasing communications in Low German, the process is currently accelerating, i.e. the readiness of the speakers to take over such structural elements taken or derivated from High German rises. On the one hand, the expected processes of convergences to New High German could be demonstrated in this structurally asymmetric constellation of Low German. On the other hand, there are multiple cases in which speakers choose hyper forms of Low German. Such hyper forms can be interpreted as a conscious rejection of and distance marker to High German. They also show, however, that speakers are (no longer) aware of the (subsistent) norms of Low German.

The relationship between Low German and High German is very insightful because both languages are historically closely related. Obviously, situations where varieties or languages are umbrellaed by a non-related standard language are also extremely interesting. Linguistic enclaves constitute such special cases, examined by Claudia Maria Riehl in her article. For the language learning process of speakers of linguistic enclave varieties, codified norms of the standard language of the country of origin usually play no or only a marginal role. Linguistic enclave communities develop their own subsistent norms. Quite frequently, language usage and the respective subsistent norms deviate significantly from the norms of the home country. As Riehl is able to show, several factors influence how close or distant norms of linguistic enclaves are to the norms of the home country. One of those factors is the language that serves as written language in the respective linguistic enclave.

The eleven articles collected in this volume thus offer the most various access to the discussed questions on norm and variation. In their entirety, they reflect the current discussion of the topic. Focusing on the object languages German and English ensures a high level of topical consistency. On the other hand, the four large topic areas (Emergence and Change of Norms and Grammatical Constructions; Relationship of Codes of Norms and 'Real' Language Usage; Competition of Standard and Non-standard Language Norms; and subsistent Norms of Minority Languages and "Institutionalised Second-language Varie- 
ties") cover a large range of relevant issues, thereby certainly giving an impetus to new and further investigations.

The contributions to this volume are based on selected lectures held during the 2007 annual conference of the Deutsche Gesellschaft für Sprachwissenschaft (DGfS) in Siegen, Germany, in the thematic session "Grammar Between Norm and Variation". Thanks are given to all participants of the thematic session who contributed to productive discussions and thereby to the success of this volume. We are obliged to Elke Joseph for critical comments (language and otherwise) and corrections. Thirdly and finally, our many thanks go to the editors of the serial VarioLingua for including this volume.

\section{References}

Abraham, Werner \& Josef Bayer, eds. 1993. Dialektsyntax (Linguistische Berichte, Sonderheft 5). Opladen: Westdeutscher Verlag.

Ammon, Ulrich. 1995. Die deutsche Sprache in Deutschland, Österreich und der Schweiz. Das Problem der nationalen Varietäten. Berlin \& New York: de Gruyter.

Auer, Peter. 1997. "Führt Dialektabbau zur Stärkung oder Schwächung der Standardvarietăt? Zwei phonologische Fallstudien". Standardisierung und Destandardisierung europäischer Nationalsprachen ed. by K. J. Mattheier \& E. Radtke, 129-162. Frankfurt/M.: Lang.

Barbiers, S., O. N. C. J. Koeneman, M. Lekakou \& M. H. van der Ham. 2008. Microvariation in Syntactic Doubling. Amsterdam: Meertens Institute.

Barbiers, S., L. Cornips \& J. P. Kunst. 2007. "The Syntactic Atlas of the Dutch Dialects (SAND): A corpus of elicited speech and text as an on-line Dynamic Atlas". Creating and Digitizing Language Corpora: Vol. 1, Synchronic Databases ed. by J. Beal, K. Corrigan \& H. Moisl. PalgraveMacmillan: Hampshire.

Barbiers, S., L. Cornips \& S. van der Kleij, eds. 2002. Syntactic Microvariation. Amsterdam: Meertens Institute Electronic Publications in Linguistics, vol. II.

Bucheli, Claudia \& Elvira Glaser. 2002. "The Syntactic Atlas of Swiss German Dialects: empirical and methodological problems". Syntactic Microvariation ed. by S. Barbiers, L. Cornips \& S. van der Kleij, 41-74. Amsterdam: Meertens Institute Electronic Publications in Linguistics, vol. II.

Cornips, Leonie \& K.P. Corrigan. 2005. Syntax and Variation. Reconciling the Biological with the Social (Current Issues in Linguistic Theory 265). Amsterdam \& Philadelphia: John Benjamins.

Daneš, František. 1968/1982. "Dialektische Tendenzen in der Entwicklung der Literatursprachen". Grundlagen der Sprachkultur, Teil 2 ed. by J. Scharnhorst \& E. Ising, 92-113. Berlin: de Gruyter. 
Daneš, František. 2006. "Herausbildung und Reform von Standardsprachen und Destandardisierung - Development and Reform of Standard Languages and Destandardization". Sociolinguistics/Soziolinguistik. An International Handbool of the Science of Language and Society / Ein internationales Handbuch zur Wissenschaft von Sprache und Gesellschaft. Band 3, Teil I. 2., vollständig neu bearbeitete und erweiterte Auflage ed. by U. Ammon, N. Dittmar, K. J. Mattheier \& P. Trudgill, 2197-2209. Berlin/New York: de Gruyter.

Deumert, Anna \& Wim Vandenbussche, eds. 2003. Germanic standardizations. Past to present. Amsterdam \& Philadelphia: John Benjamins.

Dovalil, Vit. 2006. Sprachnormenwandel im geschriebenen Deutsch an der Schwelle zum 21. Jahrhundert. Die Entwicklung in ausgesuchten Bereichen der Grammatik (Duisburger Arbeiten zur Sprach- und Kulturwissenschaft 63). Frankfurt/M.: Lang.

Dubenion-Smith, Shannon Andrew. 2007. Verbal Complex Phenomena in the West Central German Dialects. Dissertation, University of WisconsinMadison.

Duden-Grammatik. '1935. Der große Duden. Grammatik der deutschen Sprache. Bearb. von Otto Basler. Leipzig: Bibliographisches Institut.

Duden-Grammatik. ${ }^{2} 1959$. Grammatik der deutschen Gegenwartssprache ed. by Dudenredaktion \& P. Grebe (Der große Duden 4). Mannheim: Bibliographisches Institut.

Duden. 72005. Die Grammatik. Unentbehrlich für richtiges Deutsch. Duden Band 4. Mannheim \& Leipzig \& Wien \& Zürich: Dudenverlag.

Duden. ${ }^{8}$ 2009. Die Grammatik. Unentbehrlich für richtiges Deutsch. Duden Band 4. Mannheim \& Leipzig \& Wien \& Zürich: Dudenverlag.

Eroms, H. W., B. Röder \& R. Spannbauer-Pollmann. 2006. Bayerischer Sprachatlas. Sprachatlas von Niederbayern. Band 1: Einführung mit Syntaxauswertung. Heidelberg: Winter.

Fleischer, Jürg. 2002. Die Syntax von Pronominaladverbien in den Dialekten des Deutschen: eine Untersuchung zu Preposition Stranding und verwandien Phänomenen (Zeitschrift für Dialektologie und Linguistik, Beihefte 123). Stuttgart \& Wiesbaden: Steiner.

Gilles, Peter \& Claudine Moulin. 2003. "Luxembourgish". Germanic standardizations. Past to present ed. by A. Deumert \& W. Vandenbussche, 303329. Amsterdam \& Philadelphia: John Benjamins.

Gloy, Klaus. 2004. "Norm/Norm". Sociolinguistics/Soziolinguistik. An International Handbool of the Science of Language and Society / Ein internationales Handbuch zur Wissenschaft von Sprache und Gesellschaft. Band 3, Teil 1. 2., vollständig neu bearbeitete und erweilerte Auflage ed. by U. Ammon, N. Dittmar, K. J. Mattheier \& P. Trudgill, 392-399. Berlin \& New York: de Gruyter. 
Henn-Memmesheimer, Beate. 1997. "Verwendung von Elementen des StandardNonstandard-Kontinuums als Ergebnis funktionaler Handlungswahl". Norm und Variation ed. by K. J. Mattheier, 53-68. Frankfurt/M.: Lang.

Huesmann, Anette. 1998. Zwischen Dialekt und Stand: Empirische Untersuchung zur Soziolinguistik des Varietätenspektrums im Deutschen (Reihe germanistische Linguistik 199). Tübingen: Niemeyer.

Kauhanen, Irina. 2006. "Norms and Sociolinguistic Description". A Man of Measure. Festschrift in Honour of Fred Karlsson on his 60th Birthday ed. by M. Sumoninen et al. 34-46. Turku: The Linguistic Association of Finland, Special Supplement to SKY Journal of Linguistics 19.

Keller, Rudi. 1990. Sprachwandel: Von der unsichtbaren Hand in der Sprache. Tübingen: Francke.

Labov, William. 1966. The Social Stratification of English in New York City. Washington, DC: Center or Applied Linguistics.

Labov, William. 1972. Language in the Inner City: Studies in the Black Vernacular. Philadelphia: University of Pennsylvania Press.

Labov, William. 1994. Principles of Linguistic Change. Volume 1: Internal Factors. Oxford: Blackwell.

Labov, William. 2001. Principles of Linguistic Change. Volume 2: Social Factors. Oxford: Blackwell.

Ledgeway Adam. 2000. A Comparative Syntax of the Dialects of Southern Italy: A Minimalist Approach. Oxford: Blackwell.

Lenz, Alexandra. 2003. Struktur und Dynamik des Substandards. Eine Studie zum Westmilteldeutschen (Wittlich/Eifel) (Zeitschrift fur Dialektologie und Linguistik. Beihefte 125). Stuttgart: Steiner.

Maitz, Péter \& Stephan Elspaß. 2007. "Warum der 'Zwiebelfisch' nicht in den Deutschunterricht gehört". Informationen Deutsch als Fremdsprache 34(5). 515-526.

Mattheier, Klaus J., ed. 1997. Norm und Variation (Forum Angewandte Linguistik 32). Frankfurt/M.: Lang.

Mattheier, Klaus \& Edgar Radtke, eds. 1997. Standardisierung und Destandardisierung europäischer Nationalsprachen (VarioLingua 1). Frankfurt/M.: Lang.

Meinunger, André. 2008. Sick of Sick? Ein Streifzug durch die Sprache als Antwort auf den "Zwiebelfisch". Berlin: Kadmos.

Milroy, James \& Lesley Milroy. 1985. Authority in Language. Investigating Langwage Prescription and Standardisation. London \& New York: Routledge \& Kegan Paul.

Milroy, James \& Lesley Milroy. 1997. "Varieties and Variation". The Handbook of Sociolinguistics. ed. by F. Coulmas, 47-64. Oxford: Blackwell.

Paul, Hermann. 1970. Prinzipien der Sprachgeschichte. Tübingen: Niemeyer.

Penner, Zvi, ed. 1995. Topics in Swiss German Syntax. Bern: Lang. 
von Polenz, Peter. 1999. Deutsche Sprachgeschichte. Vom Spälmittelalter bis zur Gegenwart. Band 3: 19. und 20. Jahrhundert. Berlin: de Gruyter.

von Polenz, Peter. 2000. Deutsche Sprachgeschichte. Vom Spätmittelalter bis zur Gegenwart. Band 1: Einführung. Grundbegriffe, Deutsch in der frühbürgerlichen Zeit. Berlin: de Gruyter.

Schmidt, Jürgen Erich. 2005. "Die deutsche Standardsprache: Eine Varietăt drei Oralisierungsnormen". Standardvariation - Wie viel Variation verträgt die deutsche Sprache? (Jahrbuch des Instituts für Deutsche Sprache 2004) ed. by L. M. Eichinger \& W. Kallmeyer, 278-305 Berlin: de Gruyter.

Seiler, Guido. 2003. Präpositionale Dativmarkierung im Oberdeutschen (Zeitschrift für Dialektologie und Linguistik. Beihefte 124). Stuttgart: Steiner.

Sick, Bastian. 2004. Der Genitiv ist dem Dativ sein Tod. Ein Wegweiser durch den Irrgarten der deutschen Sprache. Köln: Kiepenheuer \& Witsch [and further volumes].

Spiekermann, Helmut. 2005. "Regionale Standardisierung, nationale Destandardisierung". Wie viel Variation verträgt die deutsche Sprache? (Jahrbuch des Instituts für Deutsche Sprache 2004) ed. by L. M. Eichinger \& W. Kallmeyer, 100-125. Berlin: de Gruyter.

Takahashi, Hideaki. 2004. Language Norms/Sprachnorms. Sociolinguistics/Soziolinguistik. An International Handbool of the Science of Language and Society / Ein internationales Handbuch zur Wissenschaft von Sprache und Gesellschaft. Band 3. Teil 1. 2., vollständig neu bearbeitete und erweiterte Auflage ed. by U. Ammon, N. Dittmar, K. J. Mattheier \& P. Trudgill, 172179. Berlin \& New York: de Gruyter.

Trudgill, Peter. 1983. On Dialect. Social and Geographical Perspectives. Oxford: Blackwell.

Truss, Lynne. 2005. Eats, shoots \& leaves: the zero tolerance approach to punctuation. London: Profile Books.

Weiß, Helmut. 1998. Syntax des Bairischen (Linguistische Arbeiten 391). Tübingen: Niemeyer.

Wurzel, Wolfgang U. 1984. Flexionsmorphologie und Natürlichkeit. Ein Beitrag zur morphologischen Theoriebildung (Studia Grammatica 21). Berlin: Akademie-Verlag. 